\title{
ANALISIS KEMAMPUAN KOMUNIKASI MATEMATIS SISWA DALAM PEMECAHAN MASALAH MATEMATIKA PADA MATERI SISTEM PERSAMAAN LINEAR DUA VARIABEL (SPLDV) DITINJAU DARI GAYA KOGNITIF
}

\author{
Yaumil Sitta Achir, Budi Usodo, Rubono Setiawan* \\ Prodi Pendidikan Matematika, FKIP, UNS, Surakarta
}

\begin{abstract}
This research aims at describing the students' ability in mathematical communication to solve the material Linear Equation System of Two Variables (SPLDV). This is a descriptive qualitative research. The research subjects are the students of class VIII State Junior High Sechool 16 (SMP Negeri 16) Surakarta. The data were analyzed with data the reduction technique, data presentation, and conclusion. The data were validated with time triangulation. The result shows that: 1$)$ the students' ability in mathematical communication with with Filed Dependent $(F D)$ model could account for the situation, but could not present the problems; could present mathematics entirely, but could not solve the problems, could not get solutions, and could not interpret the solution. The $F D$ students were in 1-2 level (in low-mid category); 2) the Field Independent (FI) students' mathematical communication could account for the situation, could present the problems; could present mathematics entirely and separately, could use concept and strategy, could solve the problems, could get solutions, and could interpret the solution. The FI students were in 3-4 level (in high-very high category).
\end{abstract}

Key words: Field Dependent, Field Independent, mathematical communication

\begin{abstract}
Abstrak: Penelitian ini bertujuan mendeskripsikan kemampuan dan mengetahui kemampuan komunikasi matematis siswa pemecahan masalah materi SPLDV. Penelitian ini merupakan penelitian deskriptif kualitatif. Subjek penelitian adalah siswa kelas VIII SMP Negeri 16 Surakarta. Analisis data dilakukan dengan teknik reduksi data, penyajian data, dan penarikan kesimpulan. Validitas data menggunakan teknik triangulasi waktu. Hasil penelitian disimpulkan bahwa: (1) Kemampuan komunikasi matematis siswa gaya Field Dependent (FD) mampu menjelaskan situasi, tidak mampu menyajikan permasalahan, mampu merepresentasikan matematika secara utuh, belum mampu memecahkan masalah, tidak mampu mendapatkan solusi, dan tidak mampu menafsirkan solusi. Siswa FD berada pada level 1-2 (kategori rendah-sedang); (2) Kemampuan komunikasi matematis siswa gaya Field Independent (FI) mampu menjelaskan situasi, mampu menyajikan permasalahan, mampu merepresentasi matematika secara utuh dan terpisah, mampu menggunakan konsep dan strategi, mampu
\end{abstract}

*Alamat korespondensi: Jalan Ir. Sutami 36 A. FKIP. Universitas Sebelas Maret. Surakarta.

78 e-mail: rubono.matematika@staff.uns.ac.id 
memecahkan masalah, mampu mendapatkan solusi, dan mampu menafsirkan solusi.

Siswa FI berada pada level 3-4 (kategori tinggi-sangat tinggi).

Kata kunci: field dependent, field independent, komunikasi matematis

\section{PENDAHULUAN}

Dalam kehidupan sehari-hari, seseorang tidak terlepas dari suatu komunikasi. Komunikasi dapat berlangsung antar individu, kelompok, sosial, dan lain sebagainya. Komunikasi adalah pertukaran verbal dari pemikiran dan gagasan. Dengan kata lain, komunikasi merupakan penyampaian pesan secara lisan maupun tulisan. Pada kegiatan belajar mengajar, kemampuan komunikasi sangat dibutuhkan dalam mencapai tujuan pembelajaran, salah satunya dalam pembelajaran matematika sebagaimana yang termuat dalam Peraturan Dirjen Dikdasmen No. 506/C/PP/2004 tanggal 11 November 2004 tentang Penilaian Perkembangan Anak Didik Sekolah Menengah Pertama (SMP) bahwa aspek penilaian matematika dalam rapor dikelompokkan menjadi tiga aspek, yaitu: (1) pemahaman konsep, (2) penalaran dan komunikasi, serta (3) pemecahan masalah. Latar belakang pada lampiran dokumen Standar Isi Permendiknas Nomor 22 Tahun 2006 bahwa pendekatan pemecahan masalah merupakan fokus dalam pembelajaran matematika. dalam setiap kesempatan, pembelajaran matematika hendaknya dimulai dengan pengenalan masalah yang sesuai dengan situasi (contextual problem). Sistem Persamaan Linear Dua Variabel (SPLDV) merupakan salah satu materi matematika yang menyajikan masalah sesuai situasi yang ada (contextual problem), yaitu permasalahan sederhana yang berkaitan dengan kehidupan sehari-hari. Melalui soal cerita yang mengangkat permasalahan sehari-hari ini, siswa dituntut untuk mengomunikasikan bahasa sehari-hari ke dalam bahasa matematika dan menafsirkan hasil perhitungan yang dilakukan sesuai permasalahan yang diberi untuk memperoleh suatu pemecahan (Desmita.2009).

Berdasarkan hasil observasi peneliti di kelas VIII B dan VIII D SMP N 16 Surakarta pada semester ganjil tahun ajaran 2015/2016 dan wawancara dengan guru pengampu matematika kelas tersebut, diperoleh informasi secara umum bahwa kemampuan komunikasi matematika peserta didik kelas VIII 
SMP N 16 Surakarta masih rendah. Berikut hasil observasi yang diperoleh: (1) Sebagian besar peserta didik tidak menuliskan apa yang diketahui dan ditanyakan, serta tidak memodelmatematikakan masalah kontekstual yang ada, (2) Sebagian besar peserta didik tidak menjelaskan konsep dan strategi yang mereka gunakan dalam pemecahan masalah, (3) Sebagian besar siswa tidak menafsirkan solusi masalah matematika yang ia peroleh kembali ke dalam masalah kontekstual.

Kemampuan komunikasi matematis pun berkaitan dengan gaya kognitif. Hal ini dikarenakan gaya kognitif berpengaruh terhadap pemrosesan informasi dalam otak siswa sehingga akan terjadi perbedaan penyampaian ide-ide matematis siswa pada masing-masing gaya kognitif. Setiap individu memiliki gaya kognitif yang berbeda-beda tidak terkecuali bagi siswa. Ada banyak tipe kognitif, salah satu tipe yang sering digunakan adalah gaya kognitif menurut Witkin et.al yaitu gaya kognitif Field Independent (FI) dan gaya kognitif Field Dependent (FD) (Widaningrum, K.2014).

Dari hal-hal yang telah diuraikan di atas, muncul pemikiran untuk mengadakan penelitian mengenai kemam- puan komunikasi matematis siswa ditinjau dari gaya kognitif di SMP Negeri 16 Surakarta dalam memecahkan masalah pada materi Sistem Persamaan Linear Dua Variabel (SPLDV). Adapun tujuan dari penelitian ini adalah untuk mendeskripsikan tingkat kemampuan komunikasi matematis secara tertulis siswa yang memiliki gaya kognitif FD dan FI kelas VIII SMP Negeri 16 Surakarta dalam pemecahan masalah matematika pada materi Sistem Persamaan Linear Dua Variabel (SPLDV)

\section{METODE PENELITIAN}

Penelitian ini merupakan penelitian kualitatif dengan pendekatan penelitian yaitu metode deskriptif kualitatif mengenai komunikasi matematis siswa dalam pemecahan masalah matematika pada materi sistem persamaan linear dua variabel Sistem Persamaan Dua variabel (SPLDV) ditinjau dari gaya kognitif. Penelitian ini dilaksanakan di kelas VIII B SMP N 16 Surakarta tahun ajaran 2015/2016.

Data dalam penelitian ini berupa data kemampuan komunikasi matematis secara tertulis siswa dengan sumber data utama yaitu data hasil pekerjaan siswa dalam memecahkan masalah matematika SPLDV. Subjek penelitian da- 
lam penelitian ini yaitu siswa kelas VIII B SMP N 16 Surakarta Tahun Ajaran 2015/2016 yang dipilih berdasarkan hasil pengkategorian gaya kognitif dan kemampuan awal siswa, kemudian dipilih subjek penelitian menggunakan purposive sampling untuk dilakukan wawancara berbasis tugas. Pada penelitian ini didapatkan 2 subjek dengan kategori FD dan 2 subjek dengan kategori FI.

Pengumpulan data dalam penelitian ini dilakukan dengan metode tes dan wawancara, yaitu (1) dilakukan tes gaya kognitif untuk mengkategorikan siswa ke dalam gaya kognitif FI atau FD; (2) melihat kemampuan awal siswa berdasarkan hasil ujian matematika tengah semester ganjil; (3) memilih subjek untuk dilakukan wawancara berbasis tugas dengan teknik purposive sampling.

Instrumen utama dalam penelitian ini adalah peneliti sendiri. Sedangkan instrumen bantu dalam penelitian ini berupa hasil tes gaya kognitif dan wawancara berbasis tugas. Untuk menguji keabsahan suatu data digunakan teknik validasi data yaitu triangulasi waktu. Dalam penelitian ini, triangulasi waktu digunakan untuk membandingkan data hasil tes peme- cahan masalah I dan tes pemecahan masalah II. Apabila data dari hasil tes pemecahan masalah I dengan tes pemecahan masalah II terjadi kecocokan, maka data dari subjek penelitian tersebut dapat digunakan sehingga dapat ditarik simpulan.

Prosedur yang digunakan dalam penelitian ini adalah melalui 4 tahap menurut Moleong,(2012) yaitu: tahap pralapangan; tahap pekerjaan lapangan dimana pada tahap ini peneliti melakukan tes gaya kognitif, menganalisis tes gaya kognitif, menentukan subjek wawancara, melakukan wawancara dan validasi data; tahap analisis data dimana pada tahap ini peneliti melakukan reduksi data, menyajikan data, serta menarik kesimpulan; dan tahap penyusunan laporan penelitian

\section{HASIL DAN PEMBAHASAN}

Berdasarkan hasil pengelompokkan haya kognitif, mencari subjek dengan kemampuan awal yang setara, serta konsultasi pada guru mata pelajaran matematika SMP N 16 Surakarta, proses penentuan subjek penelitian selanjutnya diambil beberapa siswa dengan teknik purposive sampling, sehingga didapatkan 4 siswa yang 
dijadikan subjek penelitian, 2 diantaranya memiliki gaya kognitif FD dan 2 lainnya memiliki gaya kognitif FI.

Data yang diperoleh selanjutnya dipaparkan, triangulasi, dan dianalisis berdasarkan indikator ketercapaian kemampuan komunikasi matematis.

Dari rangkaian prosedut tersebut di atas, didapat tiap subjek memiliki tingkat kemampuan komunikasi matematis yang berbeda. Subjek 1 FD hanya mencapai level 1 yaitu masuk dalam kategori rendah, subjek 2 FD mencapai level 2 yaitu kategori sedang, subjek 1 FI mencapai level 3 yaitu kategori tinggi, dan subjek 2 FI mencapai level 4 yaitu kategori sangat tinggi.

Dari hasil kedua subjek kategori gaya kognitif FD tersebut, diperoleh kesamaan karakteristik dari kedua subjek $F D$ yaitu :

1. Mampu menjelaskan situasi/ permasalahan dengan menyatakan hal-hal yang diketahui dan ditanyakan. Berikut merupakan penjelasan siswa terkait hal tersebut:

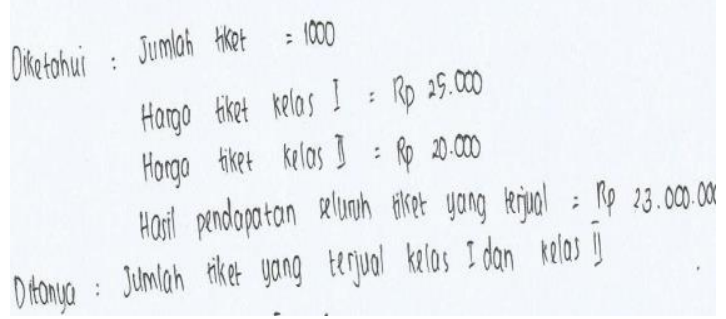

Gambar 1
2. Tidak mampu menyajikan permasalahan ke dalam model matematika dengan tepat. Berikut merupakan penjelasan siswa terkait hal tersebut:

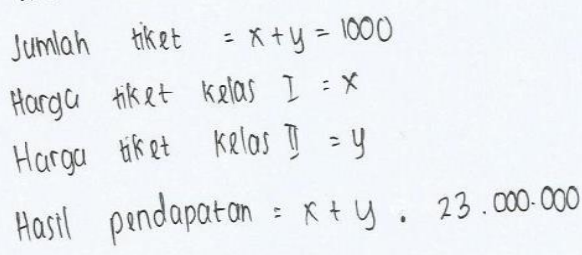

Gambar 2

3. Mampu menggunakan representasi matematika dari informasi yang tersaji secara utuh. Berikut merupakan penjelasan siswa terkait hal tersebut:

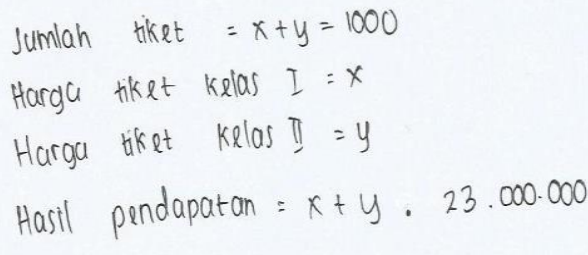

Gambar 3

4. Tidak mampu mendapatkan solusi akhir dari hasil pekerjaannya. Berikut merupakan penjelasan siswa terkait hal tersebut:

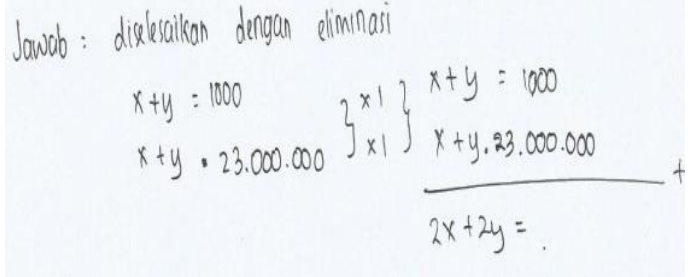

Gambar 4 
5. Tidak mampu menafsirkan solusi matematika yang ia peroleh. Berikut merupakan penjelasan siswa terkait hal tersebut:

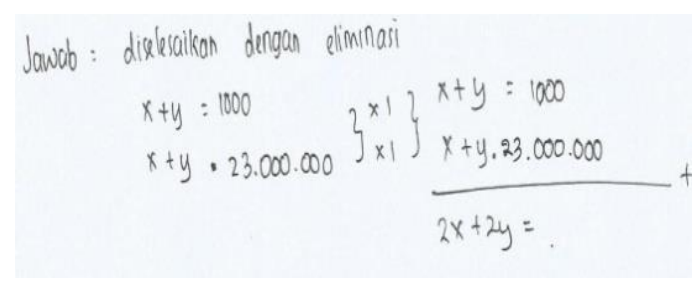

Gambar 5

Hasil analisis pada siswa FD sesuai dengan teori Witkin yang menyatakan bahwa gaya kognitif FD memiliki karakteristik sebagai berikut: kesulitan memproses informasi, cenderung hanya menerima informasi yang diberikan dan tidak mampu mengorganisasi kembali, persepsi kuat ketika dimanipulasi sesuai konteksnya namun lemah ketika terjadi perubahan konteks, sulit fokus pada satu aspek cenderung mengikuti tujuan yang sudah ada, menganalisis pola menjadi bagian-bagian yang berbeda, serta memandang objek secara global dan menyatu dengan lingkungan sekitar. Selain itu, siswa dengan gaya kognitif FD berorientasi sosial sehingga tampak baik hati, ramah, bijaksana, baik budi dan penuh kasih saying terhadap individu lain serta mengutamakan motivasi eksternal dan berpikir secara global (Witkin,dkk., 1977).
Dari hasil kedua subjek kategori gaya kognitif FI tersebut, diperoleh kesamaan karakteristik dari dua subjek FI yaitu :

1. Mampu menyatakan hal-hal yang diketahui dan dinyatakan dari permasalahan secara tepat. Berikut merupakan penjelasan siswa terkait hal tersebut:

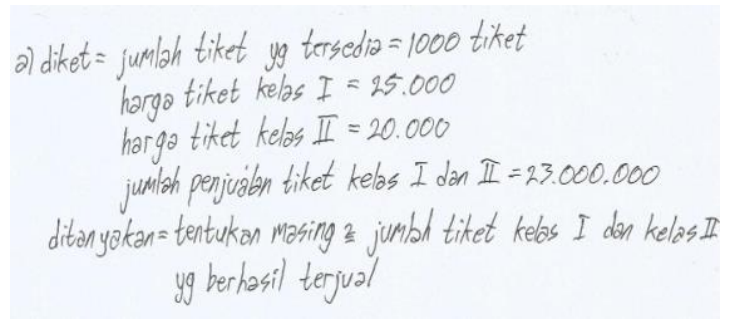

Gambar 6

2. Mampu membuat pemodelan matematika. Berikut merupakan penjelasan siswa terkait hal tersebut:

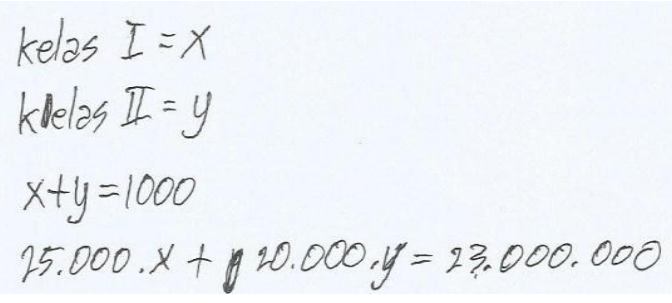

Gambar 7

3. Mampu merepresentasikan informasi yang utuh maupun yang terpisah dari informasi pada masalah ke dalam model matematika dengan tepat. Berikut merupakan penjelasan siswa terkait hal tersebut: 


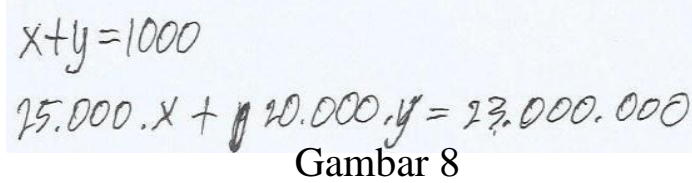

4. Mampu menggunakan konsep dan strategi yang ia pilih. Berikut merupakan penjelasan siswa terkait hal tersebut:

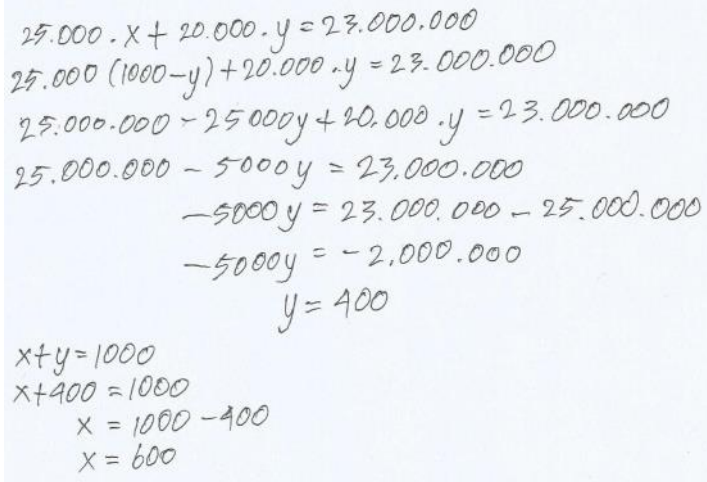

Gambar 9

5. Mampu melaksanakan langkahlangkah komputasi dalam pemecahan masalah secara tepat dan sistematis. Berikut merupakan penjelasan siswa terkait hal tersebut:

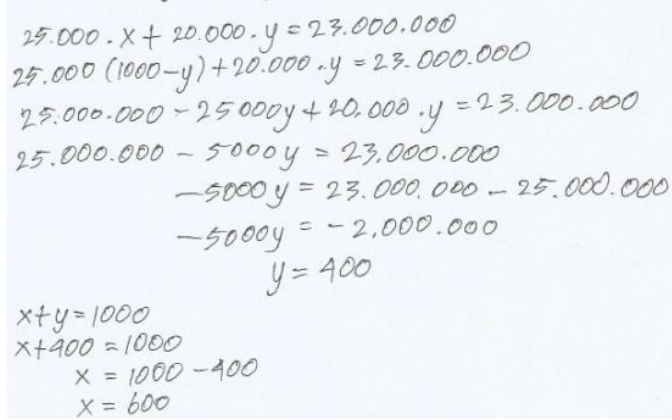

Gambar 10
6. Mampu mendapatkan solusi yang tepat dari hasil pekerjaannya. Berikut merupakan penjelasan siswa terkait hal tersebut:

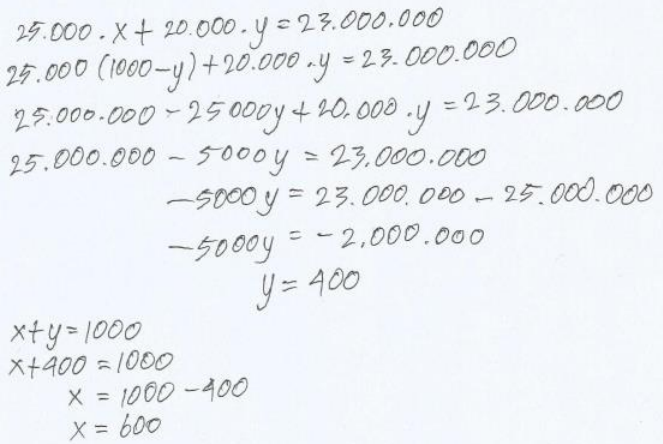

Gambar 11

7. Mampu menafsirkan solusi matematika yang diperoleh kembali ke permasalahan kontekstual. Berikut merupakan penjelasan siswa terkait hal tersebut:

jadi, lbanyak tiket kelas I adalah 600 dan kelas II sebanyake 400

Gambar 12

Hasil penelitian tersebut sesuai dengan teori Witkin yang menyatakan bahwa gaya kognitif FI memiliki karakteristik sebagai berikut: berpikir secara analitis dan mampu memproses informasi, mampu mengorganisasi objek yang belum terorganisir dan mereorganisasi objek yang sudah terorganisir, serta dapat menganalisis untuk memisahkan objek dari lingkungan sekitar 
sehingga persepsi tidak terpengaruh jika terjadi perubahan konteks dan menunjukkan bagian-bagian terpisah dari pola keseluruhan dan mampu menganalisis pola ke dalam komponenkomponennya. Selain itu, siswa dengan gaya kognitif FI berorientasi impersonal, mengutamakan motivasi internal, lebih terpengaruh oleh penguatan internal, memandang objek terdiri dari bagian-bagian diskrit dan terpisah dari lingkungan (Witkin,dkk., 1977).

Dengan demikian, gaya kognitif mempengaruhi cara seseorang untuk memproses informasi seperti ketika mengomunikasikan ide/ gagasan dalam pemecahan masalah.

Hasil penelitian ini didukung oleh penelitian Pratiwi (2013) yang menyimpulkan siswa dengan gaya kognitif FI lebih baik daripada siswa dengan gaya kognitif FD dalam kemampuan komunikasi matematis dan pemecahan masalah.

\section{KESIMPULAN}

Kemampuan komunikasi matematis siswa dengan gaya kognitif FD sebagai berikut: (a) Mampu menjelaskan situasi/ permasalahan dengan menyatakan hal-hal yang diketahui dan ditanyakan; (b) Tidak mampu menyajikan permasalahan ke dalam model matematika dengan tepat; (c) Mampu menggunakan representasi matematika dari informasi yang tersaji secara utuh; (d) Belum mampu melaksanakan langkah-langkah pemecahan masalah dengan tuntas; (e)Tidak mampu mendapatkan solusi akhir dari hasil pekerjaannya; (f)Tidak mampu menafsirkan solusi matematika yang ia peroleh

Kemampuan siswa dengan gaya kognitif FD berada pada rentang level 1-2, hal ini menunjukkan bahwa siswa dengan gaya kognitif FD memiliki kemampuan komunikasi matematis tertulis termasuk dalam kategori rendah-sedang.

Kemampuan komunikasi matematis siswa dengan gaya kognitif FI sebagai berikut : (a) Mampu menjelaskan situasi/ permasalahan dengan menyatakan hal-hal yang diketahui dan dinyatakan dari permasalahan secara tepat; (b) Mampu menyajikan permasalahan ke dalam model matematika dengan tepat; (c) Mampu menggunakan representasi matematika dari informasi yang tersaji secara utuh maupun yang terpisah dari informasi pada masalah ke dalam model matematika dengan tepat; 
(d) Mampu menggunakan konsep dan strategi yang ia pilih; (f) Mampu melaksanakan langkah-langkah komputasi dalam pemecahan masalah secara tepat dan sistematis; (g) Mampu mendapatkan solusi yang tepat dari hasil pekerjaannya; (h) Mampu menafsirkan solusi matematika yang diperoleh kembali ke permasalahan kontekstual.

Kemampuan siswa dengan gaya kognitif FI berada pada rentang level 3-4, hal ini menunjukkan bahwa siswa dengan gaya kognitif FI memiliki kemampuan komunikasi matematis tertulis termasuk dalam kategori tinggisangat tinggi.

Berdasarkan simpulan hasil penelitian di atas dapat dikemukakan saran sebagai berikut: (a) Guru matematika hendaknya lebih membimbing siswa FD dalam meng-analisis informasi yang tersaji pada soal dalam mengomunikasikan ide-ide matematisnya secara tertulis, sedangkan siswa dengan gaya kognitif FI agar lebih dibimbing dalam mengembangkan argumen saat mengomunikasikan ide matematis secara tertulis; (b) Guru matematika hendaknya memberikan evaluasi pembelajaran berupa tes uraian dengan memberikan pertanyaan berupa poin-poin yang membimbing siswa untuk mengomunikasikan ide-ide matematisnya secara tertulis sehingga siswa tidak hanya berorientasi kepada hasil; (c)Bagi peneliti lain yang ingin meneliti hal yang sejenis dengan penelitian ini dapat meneliti kemampuan komunikasi matematis siswa FI secara lisan. Hal ini diharapkan dapat memberikan pengetahuan tentang deskripsi kemampuan siswa FI dalam memberikan argumenttasi secara lisan, apakah siswa FI dapat memberikan argumentasi secara lisan lebih lengkap dan jelas dibanding argumentasi secara tertulis-nya atau tidak.

\section{DAFTAR PUSTAKA}

Depdiknas .2006. Permendiknas No 22 Tahun 2006 Tentang Standar Isi. Jakarta : Depdiknas.

Desmita. (2009). Psikologi Perkembangan Peserta Didik. Bandung: PT Remaja Rosdakarya. 
Moleong, L.J. (2012). Metode Penelitian Kualitatif (Edisi Revisi). Bandung: PT Remaja Rosdakarya.

Widaningrum, K. (2014). Analisis Kemampuan Siswa dalam Mengkomunikasikan Pemecahan Masalah Non Rutin pada Materi Segiempat ditinjau dari Adversity Quotient (AQ). Skripsi Tidak Dipublikasikan. Universitas Sebelas Maret, Surakarta.

Witkin, H.A., Moore, C.A., Goodenough, D.R., dan Cox, P. W. (1977). Fielddependent and Field-independent Cognitive Style and their Educational Implications. Review of educational Research 47. Pp. 1-64. 